\title{
Online Learning during COVID-19 Pandemic. Are Malaysian High School Students Ready?
}

\author{
Nagaletchimee Annamalai \\ School of Distance Education, Universiti Sains Malaysia, Penang, 11800, Malaysia
}

\begin{abstract}
The online learning environment is an integral part of activities conducted during the COVID-19 pandemic in schools. This study explored the Malaysian high school students' online learning perspectives using a mixed-methods study. The quantitative findings reported that students are not ready to go online. The qualitative analysis revealed several emerging themes related to students' dissatisfaction with the online learning environment. The issues are related to repository-based teaching, cognitive overload, social presence, technology comfort, and discipline. Students suggested that teachers should implement the use of standardised applications, fixed schedules, and interactive sessions. The study concluded that interactions are lacking during the online learning environment. However, the researcher hopes that once teachers are back from the COVID-19 pandemic, they will have a comprehensive understanding of technology tools to consider in their pedagogical practices. It is hoped that the post-pandemic will change the way schools and teachers perceive online learning. The sudden teaching practices during the COVID-19 pandemic will undoubtedly drive improvements in the use of technology in schools.
\end{abstract}

Keywords: COVID-19 pandemic, ICT tools, interaction, online learning

ARTICLE INFO

\section{Article history:}

Received: 5 January 2021

Accepted: 24 May 2021

Published: 13 September 2021

DOI: https://doi.org/10.47836/pjssh.29.3.06

E-mail address:

naga@usm.my

\section{INTRODUCTION}

As of $30^{\text {th }}$ March 2020, it is estimated that $87 \%$ of the students around the world, which is 1.5 billion learners, have been affected by school closures during the COVID-19 pandemic (Winthrop, 2020). As a result, schools in more than 180 countries have been shut down worldwide (UNESCO, 
2020). The global lockdown has caused a significant interruption in students' learning. To ensure that learning activities are not disrupted, UNESCO is trying to mitigate the impact of school closure and find ways to continue education for all through distance learning and education.

According to the Public Health Officials in Malaysia, flattening the curves of the COVID-19 pandemic requires months rather than weeks. To ensure limited interruptions in teaching and learning activities, former Prime Minister Tan Sri Muhyiddin Yassin has implemented home-based learning. Schools in Malaysia are encouraged to shift to the virtual learning environment. Teachers are to move to an online learning environment even if they are not familiar with technology tools. It is a responsibility that high school teachers have never imagined and something that they have never anticipated.

Integrating ICT in schools has its strengths and weaknesses, but trying to do it amid pandemics will be another problem. This reality forced students and teachers to take a crash course on technology tools, approaches, and teaching methods. The term 'panic-gogy' (Kamenetz, 2020) has been introduced when online teaching played a pivotal role during the pandemic. Teaching on a normal day during a normal week had its challenges. Sometimes a wellplanned lesson can go wrong, even in the traditional classroom. In today's situation with the COVID-19 pandemic, a lot of thinking and planning is needed for effective pedagogical practices. A teacher with the best-intended pedagogy with technology tools can still wonder about what went wrong during a well-planned lesson. In today's circumstances, the teachers have to re-think, re-plan and re-create a learning environment amid school closures and isolation.

It is not an easy endeavour as teachers have not done it before. Although several studies have been conducted on technology and education, people prefer being taught in the traditional classroom to which they are accustomed (Garba et al., 2015; Samuel \& Zaiton, 2006). The pandemic has given a unique opportunity to high schools to experience fully online education. If not for the COVID-19 pandemic, such an experience would have been impossible. The students' experiences are valuable if we are looking to draw up a new education paradigm. Much effort is needed to address the potential concerns and issues that have emerged. Therefore, this study investigated the technology tools used in the online environment during the COVID-19 pandemic. The researchers also intend to identify the students' readiness and experiences in the online environment during the COVID-19 pandemic lockdown. It has been a real shock for teachers and students to uptake technology without proper planning. There is a need to take immediate action and adapt to novel techniques to ensure that students are experiencing high-quality education in this tragic time. The research questions addressed are:

1. How ready (in terms of continued online learning, interaction to complete 
assignments, and homework completion) are students to go online during the COVID-19 pandemic?

2. What are the technology tools used during the COVID-19 online learning?

3. What are the students' experiences in the online environment during the COVID-19 pandemic?

4. What are the students' suggestions to improve the teaching and learning activities during the COVID-19 pandemic?

\section{LITERATURE REVIEW}

\section{Community of Inquiry Model}

The Community of Inquiry (CoI) model has been used widely to theorise online education by focusing on the nexus of pedagogy, technology, and learners' needs (Al-Smadi et al., 2019). CoI model is based on the work by Dewey (1938), Lipman (2003), and Pierce (1955). The model is adapted for e-learning by addressing the lens of cognitive, social, and teaching presences. Teaching presence illustrates the instructional activities for a particular course. Teachers facilitate discussion and give comments to clarify ideas to enhance learning (Garrison, 2017). The aspects related to teaching presence are Facilitating Discourse, Design and Organization, and Direct Instruction. Teaching presence also creates active and student-centred learning environments.

Meanwhile, cognitive presence reflects "a multivariate measure of critical and creative thinking that results from the cyclical process of practical inquiry within such a community of learners" (Shea et al., 2012, p. 90). It describes the phases of practical inquiry: triggering event, exploration, integration and resolution (Garrison, 2017). During the triggering event, an issue or problem is identified. Teachers often express their expectations of the task. Nevertheless, students can also initiate the triggering event. The second phase is the exploration phase where. Search for ideas, information, and knowledge makes meaning to the task being discussed. At this phase, clarification occurs. The third phase is when students are reasonably relating information and knowledge. The final phase is the resolution of the problem where it involves the application of ideas. In summary, cognitive presence involves recognising problems, exploration, resolution, and confirmation of understanding via collaboration and reflection in a community of inquiry (Garrison et al., 2000).

Social presence refers to the "social environment that supports and encourages probing questions, scepticism and the contribution of explanatory ideas" (Garrison, 2017). It creates a "climate that supports, encourages probing questions, scepticism and the contributions to explanatory ideas" (Garrison, 2011). Such conditions are illustrated through effective, interactive, and cohesive responses in group interactions (Rourke et al., 2001). Studies have demonstrated that social interaction is positively linked with learning outcomes (Mayer, 2005) and students' satisfaction (Borup et al., 2013; Richardson \& Swan, 2003). Smaller groups are said to be easily connected and promote a 
sense of community (Rovai, 2002). When learners are placed into small discussion groups, information overload repetitiveness decrease, and students are willing to interact and collaborate with others (Lowry et al., 2006). The three presences are vital to creating a community of inquiry. Studies have documented that the CoI model positively impacts on learners' satisfaction and retention rates when online learning considers teaching, cognitive and social presences (Akyol \& Garrison, 2011; Hoskins, 2012). In this study, the CoI model guides the online learning process.

\section{Technology in Educational Context}

Bringing technology into education offers various advantages, starting from offering easy access to various web materials, allowing interaction, and turning the learning environment from passive to active (Elmorshidy, 2013; Kale \& Akcaoglu, 2018; Petko et al., 2015). Online learning environments can be categorised into a triad of asynchronous, synchronous, and blended learning environments (Perveen, 2016). Asynchronous learning provides delayed feedback and discussion, where this learning provides time for reflective thinking. At the time, synchronous tools allow immediate feedback, discussions, and comments (Bower et al., 2015).

The very recent studies on education and technologies are related to mobile learning. Mobile learning such as laptops and tablets are initiatives promoted by schools and governments around the globe (Fuhrman, 2014).
Studies have also focused on handheld devices to support seamless learning, which refers to the transition of learning between formal and informal learning spaces (Hedberg \& Stevenson, 2014; Rushby, 2012). The extraordinary mobility, flexibility, and accessibility: 'Anyone, Anytime, Anywhere' offered by mobile learning has been attractive to adolescents (Annamalai \& Kumar, 2020; Park et al., 2012). Google Classroom is a popular learning management system that integrates Google Drive, Google Docs, Gmail, and Calendar. Several studies have explored the use of Google Classroom and reported positive learning outcomes (Al-Maroof \& Al-Emran, 2018; Shaharanee et al., 2016).

While informal social media are trendy for students to communicate and maintain their social relationships, they can also be effectively interwoven into an online learning environment. Twitter, also known as micro-blogging, allows the short messages (Bower et al., 2010). YouTube is often used to provide a webbased platform for users to upload and view various information. It serves as a free teaching supplement to engage students in learning (Burke et al., 2009). Annamalai et al. (2016) explored the Malaysian students' interactions on Facebook. They reported that the interactions related to teaching presence encouraged students to improve their narrative writing and promote active learning.

Researchers are also looking at innovative instructional practices. Lately, more popularly known as gamification, 
digital education has motivated and engaged students. Gamification is a well-established approach that uses game elements in a specific not-game context (Lopez \& Tucker, 2019; Werbach \& Hunter, 2012). In the educational context, it is generally observed that gamified lessons are often rivetingly engaging, motivating, and able to derive cognitive, emotional, and social benefits for learners (Chou \& Ting, 2003; Hamari \& Keronen, 2017). The 3-D virtual environments are also slowly gaining momentum. However, alongside advances in integrating ICT tools in education, schools often face challenges from various aspects. For example, Li and Ranieri (2010) discovered that students lack adequate technological skills that hinder teaching and learning activities.

At the same time, Ryan et al. (2010) discovered that techno-savvy students are ahead of the teachers and are well equipped with the latest tools, programs, and mobile technologies. Online interaction has been one of the essential aspects of meaningful experiences (Lin et al., 2017; Moore, 1989). Borup et al. (2013) highlighted that the lack of interaction in an online learning environment is considered not academically sound. Students face challenges to manage their time and take responsibility for independent learning when they use technology (Garcia et al., 2014). Studies on online readiness found that students' level of readiness can influence the level of success in online learning (Moftakhari, 2013). Machado and Chung (2015) discovered that teachers lack training and competency to integrate technology in their lessons. Anderson (2008) asserts that ICT tools are not sufficient to create thriving learning communities when used as an instruction tool to deliver content solely.

There is a low level of technology integration in schools (Kementerian Pendidikan Malaysia, 2016). Merely using ICT tools such as PowerPoint slides and videos instead of the blackboard to transmit knowledge is insufficient to add value in teaching and learning activities. A study by Samuel and Zaiton (2006) found that technical difficulties and negative attitudes are why Malaysian teachers consider technology in their classrooms. In addition to this, Garba et al. (2015) found that teachers faced limited knowledge of technology, pedagogy, content, and knowledge (TPACK) and administration issues to integrate ICT in their lesson plans. Researchers and practitioners have called for a more comprehensive and rigorous investigation of high school students' online learning (Barbour \& Reeves, 2009; Cavanaugh et al., 2009).

As illustrated, studies have indicated positive and negative experiences of using technology tools in the education context. However, there are limited studies that have been conducted during a pandemic where students experience remote and distance learning. Therefore, the study intends to fill the gap by investigating Malaysian students' readiness to go online, use ICT tools during this time, and their suggestions to improve online teaching during the COVID-19 pandemic. 


\section{METHOD}

In this study, a mixed-methods design was employed. Creswell and Clark (2007) defined a mixed-method as utilising quantitative and qualitative strength to obtain the best outcome. These methods can complement each other. Surveys and interviews were used to collect in-depth information to discern the students' experiences and suggestions related to their online learning. Solely focusing on quantitative analysis may lead to a focus on generalisation rather than understanding the students' process in learning. Therefore, the quantitative findings indicate the readiness of the students to go online and their perception of their use of social media to conduct their online lessons. On the other hand, the value of the qualitative method is to provide a deeper understanding of the phenomenon under investigation (Creswell \& Clark, 2007) and to unearth experiences that may be taken for granted (Laverty, 2003). Therefore, a qualitative study exploring the students' general practices of digital tools, online learning experience, and suggestions would be beneficial in addition to identifying the fundamental issues of concern to the high school students for their learning process during the COVID-19 pandemic.

\section{Participants}

The participants were 131 students from 5 schools in the northern region of Malaysia. Students were randomly selected to participate in this study using convenience sampling. The high school students were selected based on the researcher's convenience of access to the students. When collecting the data, students have experienced eight weeks of online learning with their teachers. Students were aged from 13-17 years old. There were $71.8 \%$ female students and $28.2 \%$ male students. All the participants were from urban schools, and they had the facilities to go online. A total of 12 students volunteered to be interviewed for this study.

\section{Questionnaire}

The survey was a questionnaire that consisted of two sections. Section A solicited demographic information such as age, sex, and school. Section B comprised items requiring information on the tools used during their learning process and students' online experience during the COVID-19 pandemic. A 5 item Likert scale online survey was developed and administered using Google Forms. From the demographic data, frequency and percentage were used. For the description of the items, frequency and percentage were used to describe the students' readiness to go online during the COVID-19 pandemic. The inter-rater reliability was not conducted since the three questions were constructed based on the studies by Händel et al. (2020) and Rafique et al. (2021). Three independent experts conducted the questionnaire's face and content validity in the online learning environment.

i. Are you ready to continue learning online during the COVID-19 pandemic?

ii. Are you ready to interact online with your friends to complete your group 
assignments during the COVID-19 pandemic?

iii. Are you ready to complete your homework online during the COVID-19 pandemic?

Quantitative data obtained were analysed using the descriptive statistics percentage (\%) to indicate the participants' interactions, collaboration, and learning performance. Statistical analysis was carried out using IBM SPSS Statistics Version 24.0.

\section{Interviews}

Telephone interviews were conducted due to social distancing and lockdown. The interviews lasted for 20-30 minutes. Prior to the commencement of the interview, all participants were given the information sheet outlining the nature of the study (via mail). In addition, pseudonyms were given to all the participants. The interview questions were about their experiences in their online learning environment. Students' interviews were recorded and transcribed verbatim. The interview questions were:

i. What are the tools used during the COVID-19 online teaching and learning activities?

ii. What are your experiences during the COVID-19 online teaching and learning activities?

iii. What are your suggestions to improve the teaching and learning activities during the COVID-19 pandemic?

Readers should note that the rich nature of qualitative data tends to indicate more than one theme in specific excerpts. Thematic Analysis by Braun and Clarke (2006) was considered to identify, analyse, interpret and report the open-ended questions. It is based on the six steps of thematic analysis: 1) becoming familiar with the data and transcribing all data; 2) generating codes; 3 ) classifying codes into themes; 4) reviewing and refining themes; 5) concisely defining and naming themes; 6) producing a report from the emerging themes which is descriptive, analytical and argumentative narrative. Direct quotations from the participants were included to explain critical themes.

The interview transcripts were coded by two experts in qualitative research. Miles and Huberman's (1994) percentage was considered. Miles and Huberman state that there must be an agreement of $70 \%$ among the coders to ensure the findings are valid. The agreement for this study was $80 \%$ for the categorisation of the themes. Members checks and peer debriefing ensured the valid information of the qualitative data. Interview transcripts were sent to participants by mail, with a request for changes and additions if needed. Peer debriefing with the coders involved justification and verification of themes. The following section will be discussed based on the research objectives.

\section{FINDINGS}

Research Question 1: How ready are students to go online during the COVID-19 pandemic? 
Table 1 illustrates the students' readiness to go online. When asked whether participants were ready to go online during the COVID-19 pandemic, $32.8 \%$ of the participants agreed (18.3\% completely agreed $+14.5 \%$ mostly agreed). In addition, $29.8 \%$ moderately agreed, and $17.6 \%$ a little agreed. Thus, fewer than half (19.8\%) of the participants indicated they were not ready to go online during the COVID-19 pandemic.

It is worth noting that $46.5 \%$ $(22.1 \%+24.4 \%)$ of the participants were ready to interact online to complete their group assignment during the COVID-19 pandemic, $24.4 \%$ moderately agreed, and $15.3 \%$ with little agreement. A total of $13.7 \%$ of the students do not agree at all to interact online to complete their assignments. More than half of the participants were ready to complete their homework online, 55.7\% $(27.5 \%+28.2 \%)$. A total of $22.9 \%$ of the participants moderately agreed to complete their homework online. A small percentage $(7.8 \%)$ of the participants agreed to little agree to complete their homework online, and $13.7 \%$ of the participants did not agree at all to complete their homework online during the COVID-19 pandemic.

Table 1

Readiness to go online

\begin{tabular}{|c|c|c|c|c|c|c|c|c|c|c|}
\hline Items & Con & etely & & tly & Mo & ately & & ttle & & it all \\
\hline & $\mathrm{N}$ & $\%$ & $\mathrm{~N}$ & $\%$ & $\mathrm{~N}$ & $\%$ & $\mathrm{~N}$ & $\%$ & $\mathrm{~N}$ & $\%$ \\
\hline $\begin{array}{l}\text { Are you ready } \\
\text { to continue } \\
\text { learning online } \\
\text { during the } \\
\text { COVID-19 } \\
\text { pandemic? }\end{array}$ & 24 & 18.3 & 19 & 14.5 & 39 & 29.8 & 23 & 17.6 & 26 & 19.8 \\
\hline $\begin{array}{l}\text { Are you ready } \\
\text { to interact } \\
\text { online with } \\
\text { your friends to } \\
\text { complete your } \\
\text { group work } \\
\text { assignments } \\
\text { during the } \\
\text { COVID-19 } \\
\text { pandemic? }\end{array}$ & 29 & 22.1 & 32 & 24.4 & 32 & 24.4 & 20 & 15.3 & 18 & 13.7 \\
\hline
\end{tabular}


Table 1 (Continued)

\begin{tabular}{|c|c|c|c|c|c|c|c|c|c|c|}
\hline \multirow[t]{2}{*}{ Items } & \multicolumn{2}{|c|}{ Completely } & \multicolumn{2}{|c|}{ Mostly } & \multicolumn{2}{|c|}{ Moderately } & \multicolumn{2}{|c|}{ A Little } & \multicolumn{2}{|c|}{ Not at all } \\
\hline & $\mathrm{N}$ & $\%$ & $\mathrm{~N}$ & $\%$ & $\mathrm{~N}$ & $\%$ & $\mathrm{~N}$ & $\%$ & $\mathrm{~N}$ & $\%$ \\
\hline $\begin{array}{l}\text { Are you } \\
\text { ready to } \\
\text { complete your } \\
\text { homework } \\
\text { online during } \\
\text { COVID -19 } \\
\text { pandemic? }\end{array}$ & 36 & 27.5 & 37 & 28.2 & 30 & 22.9 & 10 & 7.8 & 18 & 13.7 \\
\hline
\end{tabular}

Research Question 2: What are the tools used during the COVID-19 online teaching and learning activities?

Asynchronous and Synchronous Tools. The student (PI) indicated that her class has been experiencing asynchronous discussion. Teachers have been giving assignments, homework, and worksheets via Google Classroom and Telegram. According to P1, "my Physics teacher has been using Zoom to have a face-to-face discussion in the virtual environment". However, P1 found it inconvenient to go synchronous because all the students were not fortunate to have an Internet connection. P1 is not in favour of synchronous discussion because "it is inconvenient and the learning process is much slower. All students can be online at the same time. I rather have my assignments and notes uploaded in Google form or email and I can do it at my own pace."

P2 concurred with P1 in this respect and highlighted that Google classroom is helpful compared to WhatsApp and Telegram because "Google Classroom has due dates and after the dates, you cannot submit the assignment." With WhatsApp and Telegram, such a feature is not available. $\mathrm{P} 2$ also found that the "Internet connection is weak and depends on the broadband." P5 highlighted that "the teacher gives us homework via Google classroom and answers also provide the marking scheme and ask us to mark the exercises." Another teacher conducted a virtual face to face interaction by using Microsoft Teams. P6 said that "the teacher puts on the slides and also links. I prefer the Microsoft team because you can send messages to the teachers. "Students elaborated on the use of Microsoft Teams, and students found "the video quality is better than Google Meet" (P8). Teachers also sent "online video links" (P9). Some of the students appreciated it when the teacher recorded their teaching and uploaded the lessons on YouTube. P7 felt it was such an "effective approach because they can go back to look at it" and "if there are any doubts." One of the students expressed her satisfaction since "we can leave our message in the comments section and the teacher will get back to us" (P6). 
Research Question 3: What are the students' experiences during the COVID-19 online teaching and learning activities?

The following section presents the emerging themes based on the research questions.

\section{Repository Based Nature}

The participants found that the online learning environment was used for repository materials where teachers assigned "homework" (P1, P4, P5), "upload notes (P2, P3)" and "provide answers" (P1, P4, P9, P11). These online environments appeared to be an essential virtual platform to share materials and backup or historical records. Students have been passively receiving knowledge. $\mathrm{P} 3$ encapsulated these ideas:

"The teachers probably talk for one hour. They open the camera and start talking. They want to confirm whether students are attending their classes. It is better for teachers to give homework, and we can complete it". (P3)

Similarly, P11 highlighted that:

"The teaching is boring during online classes because only the teacher is explaining. If it is in the classroom, one of us will be called to explain. I prefer to have homework. I have a lot more time to refer to the books, but the teacher wants the homework the next day”. (P11)

The teacher talks, and students exclusively listen. Students work alone, and there was no opportunity for interaction and collaboration. Students highlighted their dissatisfaction when "the learning is not effective (P12)," "give homework and students will figure out themselves" (P5), "gives modules to do" (P7), and "monitor cannot reply" (P2). One of the participants suggested that "I would like the teachers to turn on the camera and ask us to show our answers. That will make us complete the exercises given" (P10).

They felt that the teachers were passive technology users. They stuck at a basic level and did not attempt to use advanced or sophisticated tools. One student pointed out, "some teachers are not good in technology" (P4). Therefore, another student suggested, "I think Discord app is good" and "very organised and can accommodate more than a thousand students, we can submit assignment chat group and we, can also draw." Another student emphasized that "online learning is not suitable for certain subjects. It is good for English, History but not for Science subjects" (P9). Teachers were teaching very fast, and students had difficulties coping with what is being taught. It is because teachers could not exactly "notice the students and students are not playing their part to ask questions. The teachers assume that everyone understands and they move on" (P11).

Cognitive Overload. Students were barraged with many ideas and concepts from teachers. Therefore, students had difficulties coping with the lessons taught. Much information was delivered on the same day. However, the students could not understand what was taught, and they had 
difficulties recalling information for later use. The following statement is a typical comment from the interview:

"I feel teaching is not taking place. The teacher thinks they are teaching. All the subjects are planned for the same day, and I have no time to follow the lessons. We have been watching the screen for the whole day. There is sometimes 15 minutes' gap from one lesson to another. My tuition teachers are also using Zoom and WhatsApp to teach their lessons. I have to sleep late to finish my homework. No time to watch all the lessons". (P2)

Students were inundated and overwhelmed with homework. P11 revealed that "In Google classroom, they gave a few assignments at once and every day you have to complete them. Each subject teachers give a few assignments with the same dateline." Another student realised that "the teacher has been giving more homework online than traditional classroom teaching. Besides, they give us a quiz and expect us to understand the topic". (P4)

Social Presence. A significant difference between traditional classroom teaching and the online learning environment is in the area of social presence. The interviews revealed that the participants have relatively little interaction among peers. Apart from sharing the materials and worksheets, the students stated that the online learning environment had not allowed them to interact with class members. For example, "I am missing my friends. I have to call them to maintain our friendship. I cannot wait to go back to school" (P5). The lack of face-to-face interaction minimises peer support which many students find helpful in their learning process. One student explained:

"School is not boring because there is always a conversation in the class. When you do not understand, you can ask your friends sitting beside you, but in recorded lessons, you have to watch the recorded lesson till the end". (P11)

They felt isolated, and the absence of support from peers made learning in the virtual environment a significant adjustment for some students. However, they realized that it is wise to go online till the lockdown is lifted. One student explained:

"I am very grateful to the school and teachers because they are sending us videos and notes. At least $50 \%$ of the syllabus is covered. When the school starts, we hope the teachers will have extra classes to cover the syllabus". (P2)

Similarly, another student highlighted that: "It is better to have something. We are having our SPM (Public examination). It is okay for other forms without exams. I want to pass my exam with flying colours. I am okay with any source that helps me until the school reopens". (P3)

Technology Comfort. Online learning requires the teacher as well as the students to have technology comfort. The Internet downtime and technology glitches from the teachers and the students can prohibit effective teaching and learning activities. 
Students expressed their frustration: "We have Wi-Fi problems, and for this reason, some of my friends' skip classes" (P1). P1 prefers asynchronous discussions because the "Internet is slow and I do not find it convenient" and "sometimes the connection is bad, I cannot hear the teacher". Another student lamented that "I do not have a printer at home. I have to print my worksheets."

Furthermore, "the Internet packages are different, and I have difficulties following the lessons. Sometimes I use the smartphones, but it is inconvenient because any work related to Microsoft is difficult to do in the smartphone especially Excel sheet, very difficult to edit" (P11). In addition to this, "we also have teachers who asked us to use Pdf and Jpeg the pictures and send it to them. I have no idea what Jpeg is" (P7).

With lockdown and social distancing, all families were very dependent on computers and laptops. As a result, there has been an increased use of online services. One of the students shared her problem that "there is only one laptop and my mother is a teacher. She needs to use it to teach her students. Everybody will be fighting for it" (P4). (P8) claimed that her eyesight was getting worse "because I have been sitting in front of the laptop the whole day." Meanwhile, (P12) stated that "my neck is painful because looking at the screen too often."

Discipline. In the class, the teacher uses discipline to ensure that students are attentive, orderly and controlled. Students are quiet and able to retain complete control of the learning activities. However, being online, students tended to wander and could be distracted at times. For example, "I wake up late. Rush to follow the online lessons. Our attendance is not monitored. I can switch off the camera and go to sleep again. No one is monitoring" (P2). Distraction at home, such as family and chores, could put students away from their online classes, and "I have to take care of my little brother who is five years old?" (P6). However, some students also felt that although they were not disciplined during this lockdown, they could "study even if they wake up late" (P9).

\section{Research Question 4: What are students' suggestions to improve the teaching and learning activities during the COVID-19 pandemic?}

Standardised Application Use. They emphasised that there was a need to standardise the apps used. It is because students found it cumbersome to upload several applications. One of the students suggested that:

"Sometimes we use Google classroom, sometimes Zoom. We keep downloading different apps and tools". So we have to switch to several apps. They need to standardize the use of apps." (P8)

Similarly, P11 suggested that "different apps take up much storage in the phone or laptop. I find it difficult to switch apps for different classes."

Fixed Schedule. Some of the students suggested a fixed schedule to avoid "classes that clashes" (P2). Therefore "students 
need to choose which class they want to attend. All teachers give classes at the same time, so we are not able to attend all the classes" (P2). Furthermore, students wanted the teachers to "inform in advance" (P7) and "they should space out the lessons for a week" (P8). Also, students expected teachers to give notes and exercises much earlier so that they will be prepared. Further, too many students seem to attend online classes. One student explained:

"In Google meet, there are several classes in Form 5 (17-year-old), and the whole form is attending the lessons. Therefore, we need to follow our subject teachers. A fixed timetable like what has been implemented in school has to be considered". (P6)

\section{DISCUSSION AND PEDAGOGICAL IMPLICATIONS}

It appears that the COVID-19 pandemic has enhanced the use of online learning in Malaysian schools. Previous studies have indicated the low use of technology in Malaysian schools. However, during these unprecedented times, teachers have flocked to the virtual environment to support their students. The quantitative findings indicate that most students are ready to go online, and only a tiny percentage of students do not agree to go online. The emerging themes from the interviews highlight their positive and negative experiences.

Students were exposed several asynchronous and synchronous tools. The findings revealed that teachers have used various technology tools. However, they are not fully prepared to integrate technology effectively as the shift was sudden. The teachers seemed to 'extend' their online teacher-centeredness by providing content and answers. There are no constructive interactions as suggested by the CoI model. The transmission of knowledge from teacher to student is in a linear direction. The teacher speaks about specific content, and the lesson ends with homework and worksheets. The finding is in line with Annamalai et al. (2015), who found that although technology is available to interact and collaborate, the approach taken by the Malaysian teachers is still teacher-centred. If teachers wish to change the teaching and learning activities, the mere use of technology tools will not suffice. This finding also reinforces Garba et al. (2015) findings that Malaysian teachers lack TPACK to integrate ICT effectively in the classroom.

Therefore, the teacher's role in this online learning can be seen as a medium "to complete a particular task, rather than an opportunity to engage in rich discussion and debate with their peers and instructors," as proposed by Hara et al. (2000, p. 148). Borup et al. (2013) assert that the lack of interaction in an online learning environment is viewed as not academically sound. Studies have indicated that integrating technology tools in the teaching process is a difficult task. Although technology in isolation seems effective, the effect is not the same in natural education settings (Sivo et al., 2018).

Therefore, teachers need to encourage group activities and interaction as suggested by the CoI model. The CoI model is based on the social constructivism 
theory, emphasising scaffolding and Zon of Proximal Development (ZPD) to guide students in their journey to acquire knowledge (Vygotsky, 1978). ZPD is the distance between students' ability to carry out a task under an adult or peer's interaction allowing the learners to be more conscious. Cognitive presence suggested by Garrison et al. (2000) for effective online learning involves recognizing problems, exploration, integration, and resolution phases. However, these phases are not evident in this study. Encouraging such phases in an online environment is essential for teachers to deliver their content more effectively.

We need to consider that teachers cannot be experts overnight. Trial and error must be the starting point for teachers and students to go online. This study shows that a mix of tools has been used in their learning process. By now, teachers would have discovered what works and what does not work based on the subject, content, and skills being taught. A mix and match of tools with appropriate pedagogical practices will lead to positive learning outcomes. As Netolicky (2020, p. 18) pointed out, "learning that shifts beliefs, and thereby behaviours, of professionals. It is tied to an individual's personal and professional identity". With the rapid change experienced by teachers, in situ learning occurs at their point of need. It can be a starting point as teachers are getting familiar with the appropriate online pedagogical practices.

Students have highlighted their dissatisfaction related to cognitive load. One of the essential aspects of any learning is to ensure that the content is delivered effectively, understood, and recalled when necessary. As such, practical instructions should always consider the amount of knowledge instilled. The more information delivered at one time, the more likely students will not remember. According to Cognitive Load Theory (Sweller, 1988), students can only remember what has been taught if ideas and information do not overload their mental capacity. The theory highlighted that the working memory capacity is limited. Therefore, too much information presented simultaneously becomes overwhelmed, and most of the information is lost. One of the ways to reduce cognitive load is to keep the lessons short. Sweller (2020) suggested that to reduce cognitive load teachers need to keep information simple and use various instructional techniques. For example, offer some information verbally and visually. Thus, it enables the students to absorb information with different processing methods and bite-size learning. Bite-size learning is another approach to convey information effectively. Annamalai (2019) found that students prefer ideas presented in short modules and chunks when WhatsApp was used to deliver information for students. In other words, students prefer bite-size learning.

The findings also suggest that students are not connected with their peers during online learning. Students engaged online need social and emotional support, particularly during the COVID-19 pandemic because students are being isolated from 
friends. Social presence is an essential aspect of online learning. Learners are not only looking for information; they are also looking for affiliation, support, and affirmation" (Sproull \& Faraj, 1997, p. 38). Similarly, online learning involves social aspects, and social interactions are at the heart of the learning process (Rovai, 2002; Sung \& Mayer, 2012). According to Kreijns et al. (2004), online learners are expected to form friendships. Dialogic and constructive pedagogy activities such as Socrative questioning, gamification, and peer review might be some of the options to encourage social presence. It is pertinent for teachers to set a conducive environment from the beginning of the lessons. Probably ice-breaking sessions would be a good start. Students can share personal stories of what happened during the weekend. Students can also upload videos about a topic, which allows comments from peers and teachers. Off-topic, discussions could also take place to help students and teachers to maintain their relationships.

Technical problems have always been an issue in the online learning environment. The adequate support of tools is essential for learning to take place. Since the pandemic was not predicted, technology discomfort has been experienced, and this can be overcome once the lockdown is over. Doucet et al. (2020, p. 8) put forward the idea "Maslow before Bloom," indicating that although teaching and learning activities are essential, health and safety need to be given the utmost priority during a crisis. This is because students are experiencing complexities from home as well as mental, emotional, and physical strain. Once the pandemic is over, both the teachers and students will handle online learning exceptionally well. Self-discipline seems to be essential. However, this is not the school environment. Learners will struggle with motivation and engagement. Schools need to inform the parents about the online classes. Parents can help to check the disciplines of the students from home.

\section{CONCLUSION}

The global lockdown was never expected. COVID-19 is a global pandemic, and schools are trying to go online amid significant health and economic crises. There will be challenges from school, teachers, parents, and students. However, the qualitative and quantitative findings have indicated that students are ready to go online. The study points to students' need for support in social, emotional, and pedagogical aspects. The findings should contribute to a better understand of the sudden change to online learning in high schools and lead to conclusions for educational practice. It will guide teachers and students to discover their experiences and slowly overcome the weaknesses they experience. Due to the crisis, a great deal of flexibility is needed in the learning process. However, the findings are too significant to be ignored. Understanding the problems and considering the appropriate strategies is essential to maintaining quality, motivation, and engagement. 
This study has several takeaways, but the primary conclusion is that teaching must be interactive and student-centred when students are engaged in the virtual environment. The current study has some limitations, which should be considered in future research. Longitudinal studies should also be considered for a more comprehensive understanding of the online environment in schools. In addition to this, the study was only conducted in high schools in the northern region of Malaysia. Future studies should consider other regions in Malaysia.

\section{ACKNOWLEDGEMENT}

The authors wish to acknowledge the USM Short term grant 304/PJJAUH/ 6315231 for the financial support.

\section{REFERENCES}

Akyol, Z., \& Garrison, D. R. (2011). Assessing metacognition in an online community of inquiry. The Internet and Higher Education, 14(3), 183-190. https://doi.org/10.1016/j. iheduc.2011.01.005

Al-Maroof, R. A. S., \& Al-Emran, M. (2018). Students acceptance of Google classroom: An exploratory study using PLS-SEM approach. International Journal of Emerging Technologies in Learning, 13(6), 112-123. https://doi.org/10.3991/ijet.v13i06.8275

Al-Smadi, M., Talafha, B., Al-Ayyoub, M., \& Jararweh, Y. (2019). Using long short-term memory deep neural networks for aspect-based sentiment analysis of Arabic reviews. International Journal of Machine Learning and Cybernetics, 10(8), 2163-2175. https://doi.org/10.1007/s13042018-0799-4
Anderson, T. (2008). The theory and practice of online learning (2nd ed.). Athabasca University (AU) Press.

Annamalai, N. (2016). Exploring the writing approaches in the Facebook environment. Teaching English with Technology, 16(1), 71-87.

Annamalai, N. (2019). Using WhatsApp to extend learning in a blended classroom environment. Teaching English with Technology, 19(1), 3-20.

Annamalai, N., Tan, K. E., \& Abdullah, A. (2016). Teaching presence in an online collaborative learning environment via Facebook. Pertanika Journal of Social Sciences \& Humanities, 24(1), 197-212.

Annamalai, N., \& Kumar, J. A. (2020). Understanding smartphone use behavior among distance education students in completing their coursework in English: A Mixed-Method Approach. The Reference Librarian, 6(3) 199215.

Annamalai, N., Eng, T. K., Abdullah, A., \& Sivagurunathan, S. (2015). Exploring the Interactions on an online narrative writing platform. Malaysian Journal of Learning and Instruction, 12, 103-129.

Barbour, M. K., \& Reeves, T. C. (2009). The reality of virtual schools: A review of the literature. Computers \& Education, 52(2), 402-416. https:// doi.org/10.1016/j.compedu.2008.09.009

Borup, J., West, R. E., \& Graham, C. R. (2013). The influence of asynchronous video communication on learner social presence: A narrative analysis of four cases. Distance Education, 34(1), 48-63. https://doi.org/10.1080/01587919.2013.770427

Bower, M., Dalgarno, B., Kennedy, G. E., Lee, M. J., \& Kenney, J. (2015). Design and implementation factors in blended synchronous learning environments: Outcomes from a cross-case analysis. Computers \& Education, 86, 1-17. https://doi.org/10.1016/j.compedu.2015.03.006 
Bower, M., Hedberg, J. G., \& Kuswara, A. (2010). A framework for Web 2.0 learning design. Educational Media International, 47(3), 177198. doi:10.1080/09523987.2010.518811

Braun, V., \& Clarke, V. (2006). Using thematic analysis in psychology. Qualitative Research in Psychology, 3(2), 77-101. https://doi. org/10.1191/1478088706qp063oa

Burke, S. C., Snyder, S., \& Rager, R. C. (2009). An assessment of faculty usage of YouTube as a teaching resource. Internet Journal of Allied Health Sciences and Practice, 7(1), 8.

Cavanaugh, W. J., Tocci, G. C., \& Wilkes, J. A. (2009). Architectural acoustics: Principles and practice. John Wiley \& Sons.

Chou, T. J., \& Ting, C. C. (2003). The role of flow experience in cyber-game addiction. Cyber Psychology \& Behavior, 6(6), 663-675. https:// doi.org/10.1089/109493103322725469

Creswell, J. W., \& Clark, V. L. (2007). Designing and conducting mixed method research. Sage.

Dewey, J. (1938). Experience and education. Collier Books.

Doucet, A., Netolicky, D., Timmers, K., \& Tuscano, F. J. (2020). Thinking about pedagogy in an unfolding pandemic. https://www.saspa. com.au/wp-content/uploads/2020/04/2020_ Research_COVID-19_2.0_ENG-Thinkingabout-Pedagogy-in-an-Unfolding-Pandemic.pdf

Elmorshidy, A. (2013). Applying the technology acceptance and service quality models to live customer support chat for e-commerce websites. Journal of Applied Business Research, 29(2), 589-596. https://doi. org/10.19030/jabr.v29i2.7659

Fuhrman, T. (2014, March 20). A mobile initiative that's more than just a tablet handout. Campus Technology. http://campustechnology.com/ articles/2014/03/20/a-mobile-initiative-thatsmore-than-just-a-tablet-handout.aspx
Garba, S. A., Byabazaire, Y., \& Busthami, A. H. (2015). Toward the use of 21 st century teachinglearning approaches: The trend of development in Malaysian schools within the context of Asia Pacific. International Journal of Emerging Technologies in Learning, 10(4), 72-79. http:// dx.doi.org/10.3991/ijet.v10i4.4717

Garcia, A., Abrego, J., \& Calvillo, M. (2014). Study of the of hybrid instructional delivery for graduate students in an educational leadership course. International Journal of E-Learning \& Distance Education, 29(1), 1-15.

Garrison, D. R. (2017). E-learning in the 21st century. Routledge.

Garrison, D. R., Anderson, T., \& Archer, W. (2000). Critical thinking, cognitive presence, and computer conferencing in distance education. American Journal of Distance Education, 15(1), 7-23. https://doi. org/10.1080/08923640109527071

Garrison, D. R. (2011). E-learning in the 21st century: A framework for research and practice. http://jofdl.nz/index.php/JOFDL/article/ viewFile/133/98

Hamari, J., \& Keronen, L. (2017). Why do people play games? A meta-analysis. International Journal of Information Management, 37(3), 125-141. https://doi.org/10.1016/j.ijinfomgt.2017.01.006

Händel, M., Stephan, M., Gläser-Zikuda, M., Kopp, B., Bedenlier, S., \& Ziegler, A. (2020). Digital readiness and its effects on higher education students' socio-emotional perceptions in the context of the COVID-19 pandemic. Journal of Research on Technology in Education, Aheadof-Print, 1-13. https://doi.org/10.1080/1539152 3.2020 .1846147

Hara, N., Bonk, C. J., \& Angeli, C. (2000). Content analysis of online discussion in an applied educational psychology course. Instructional Science, 28(2), 115-152. 
Hedberg, J. G., \& Stevenson, M. (2014). Breaking away from text, time and place. In M. G. D. Ifenthaler (Ed.), Curriculum models for the 21st century (pp. 17-33). Springer.

Hoskins, B. J. (2012). Connections, engagement, and presence. The Journal of Continuing Higher Education, 60(1), 51-53. https://doi.org/10.108 0/07377363.2012.650573

Kale, U., \& Akcaoglu, M. (2018). The role of relevance in future teachers' utility value and interest toward technology. Educational Technology Research and Development, 66(2), 283-311.

Kamenetz, A. (2020). Panic-gogy: Teaching online classes during the coronavirus pandemic. OPB. Retrieved April 5, 2020, from https:// www.opb.org/news/article/npr-panic-gogyteaching-online-classes-during-the-coronaviruspandemic/

Kementerian Pendidikan Malaysia. (2016). Malaysian education blue print 2013-2025. https:// www.moe.gov.my/menumedia/media-cetak/ penerbitan/dasar/1207-malaysia-educationblueprint-2013-2025/file

Kreijns, K., Kirschner, P. A., Jochems, W., \& Van Buuren, H. (2004). Determining sociability, social space, and social presence in (a) synchronous collaborative groups. CyberPsychology \& Behavior, 7(2), 155-172.

Laverty, S. M. (2003). Hermeneutic phenomenology and phenomenology: A comparison of historical and methodological considerations. International Journal of Qualitative methods, 2(3), 21-35.

Li, Y., \& Ranieri, M. (2010). Are 'digital natives' really digitally competent?-A study on Chinese teenagers. British Journal of Educational Technology, 41(6), 1029-1042. https://doi. org/10.1111/j.1467-8535.2009.01053.x

Lin, C.-H., Zheng, B., \& Zhang, Y. (2017). Interactions and learning outcomes in online language courses. British Journal of Educational Technology, 48(3), 730-748. https://doi. org/10.1111/bjet. 12457

Lipmann, M. (2003). Thinking in education. Cambridge University Press.

Lopez, C. E., \& Tucker, C. S. (2019). The effects of player type on performance: A gamification case study. Computers in Human Behavior, 91, 333345. https://doi.org/10.1016/j.chb.2018.10.005

Lowry, P. B., Roberts, T. L., Romano Jr, N. C., Cheney, P. D., \& Hightower, R. T. (2006). The impact of group size and social presence on small-group communication: Does computer-mediated communication make a difference? Small Group Research, 37(6), 631-661. https://doi. org/10.1177/1046496406294322

Machado, L. J., \& Chung, C. J. (2015). Integrating technology: The principals' role and effect. International Education Studies, 8(5), 43-53.

Mayer, R. E. (2005). The Cambridge handbook of multimedia learning. Cambridge University Press.

Miles, M. B., \& Huberman, A. M. (1994). Qualitative data analysis: An expanded sourcebook. Sage.

Moftakhari, M. M. (2013). Evaluating e-learning readiness of faculty of letters of Hacettepe. [Master's thesis]. Hacettepe University.

Moore, M. G. (1989). Three types of interaction. The American Journal of Distance Education, 3(2), 1-6.

Netolicky, D. M. (2020). Transformational professional learning: What, why and how? Independent Education, 50(1), 32-33.

Park, S.Y., Nam, M.-W., \& Cha, S.-B. (2012). University students' behavioral intention to use mobile learning: Evaluating the technology acceptance model. British Journal of Educational Technology, 43(4), 592-605. https://doi. org/10.1111/j.1467-8535.2011.01229.x 
Perveen, A. (2016). Synchronous and asynchronous e-language learning: A case study of virtual university of Pakistan. Open Praxis, 8(1), 21-39.

Petko, D., Egger, N., Cantieni, A., \& Wespi, B. (2015). Digital media adoption in schools: Bottom-up, top-down, complementary or optional? Computers \& Education, 84, 49-61.

Pierce, C. S. (1955). The fixation of belief. In J. Buchler (Ed.), Philosophical writings of Pierce (pp. 5-22). Dover.

Rafique, G. M., Mahmood, K., Warraich, N. F., \& Rehman, S. U. (2021). Readiness for online learning during COVID-19 pandemic: A survey of Pakistani LIS students. The Journal of Academic Librarianship, 47(3), 102346.

Richardson, J. C., \& Swan, K. (2003). Examining social presence in online courses in relation to students' perceived learning and satisfaction. Journal of Asynchronous Learning Networks, 7(1), 119-130. http://hdl.handle.net/2142/18713

Rourke, L., Anderson, T., Garrison, D. R., \& Archer, W. (2001). Methodological issues in the content analysis of computer conference transcripts. International Journal of Artificial Intelligence in Education, 12(1), 89-107.

Rovai, A. P. (2002). Development of an instrument to measure classroom community. Internet and Higher Education, 5(3), 197-211. https://doi. org/10.1016/S1096-7516(02)00102-1

Rushby, N. (2012). Editorial: An agenda for mobile learning. British Journal of Educational Technology, 43(3), 355-356. https://doi. org/10.1111/j.1467-8535.2012.01313.x

Ryan, J., Scott, A., \& Walsh, M. (2010). Pedagogy in the multimodal classroom: An analysis of the challenges and opportunities for teachers. Teachers and Teaching: Theory and Practice, 16(4), 477-489. https://doi. org/10.1080/13540601003754871
Samuel, R., \& Bakar, Z. (2006). The utilization and integration of ICT tools in promoting English language teaching and learning: Reflections from English option teachers in Kuala Langat District, Malaysia. International Journal of Education and Development using ICT, 2(2), 4-14.

Shaharanee, I. N. M., Jamil, J. M., \& Rodzi, S. S. M. (2016, August). Google classroom as a tool for active learning. AIP Conference Proceedings, $1761(1), 020069$.

Shea, P., Hayes, S., Smith, S. U., Vickers, J., Bidjerano, T., Pickett, A., \& Jian, S. (2012). Learning presence: Additional research on a new conceptual element within the Community of Inquiry (CoI) framework. The Internet and Higher Education, 15(2), 89-95. https://doi. org/10.1016/j.iheduc.2011.08.002

Sivo, S. A., Ku, C. H., \& Acharya, P. (2018). Understanding how university student perceptions of resources affect technology acceptance in online learning courses. Australasian Journal of Educational Technology, 34(4), 72-91. https:// doi.org/10.14742/ajet.2806

Sproull, L., \& Faraj, S. (1997). Atheism, sex, and databases: The net as a social technology. Culture of the Internet, 16(3), 35-51.

Sung, E., \& Mayer, R. E. (2012). Five facets of social presence in online distance education. Computers in Human Behavior, 28(5), 1738-1747. https:// doi.org/10.1016/j.chb.2012.04.014

Sweller, J. (1988). Cognitive load during problem solving: Effects on learning. Cognitive Science, 12(2), 257-285.

Sweller, J. (2020). Cognitive load theory and educational technology. Educational Technology Research and Development, 68(1), 1-16. https:// doi.org/10.1016/0364-0213(88)90023-7

UNESCO. (2020). COVID-19. Education disruption and response. https://en.unesco.org/covid19/ educationresponse 
Vygotsky, L. (1978). Mind in society: The development of higher psychological processes. Harvard University Press.

Werbach, K., \& Hunter, D. (2012). For the win: How game thinking can revolutionize your business. Wharton Digital Press.
Winthrop, R. (2020, March 31). COVID-19\& school closure: Why can countries from past emergencies. Brookings. https://www. brookings.edu/research/covid-19-and-schoolclosures-what-can-countries-learn-from-pastemergencies/ 